\title{
양허성 차관의 새로운 증여율 측정방식과 ODA 변화
}

정우용(KOICA 월드프렌즈본부장)

목 차

1. 머리말

2. 새 할인율 적용에 따른 증여율의 변화

3. 새 증여율과 ODA 변화

4. 결론 및 시사점

제 I장

제I장

제피장

최근 $\mathrm{OECD}$ 개발원조위원회(DAC) 고위급(HLM)회의(2014.12)에서는 현행 양허성 차관(concessional loans)의 증여율(grant element) 측정방식을 변경하는데 합의하 고 이를 반영하여 새롭게 공적개발원조(ODA)의 개념을 정의 내리게 되었다. 특히, 기존 양허성 차관의 해석과 측정방식에 대한 공여국간 이견과 문제점 등이 지난 10 여 년 이상 제기되어 오다가 1972 년에 설정된 측정방식이 비로소 변경된 것이다.

$\mathrm{OECD} \mathrm{DAC} \mathrm{회원국} \mathrm{중} 11$ 개 국가가 제공하고 있는 양허성 차관은 무상원조와 함께 $\mathrm{ODA}$ 를 구성하는 주요한 개발재원으로서 매년 1,300 억불의 ODA 재원 중 약 300 억 불이 양허성 차관의 형태로 개도국에 지원되고 있다. 그러나 ODA 통계 보고에 있어 현행 순지출방식의 ODA 계상은 양허성 차관의 원금 상환으로 인한 자금의 흐름 (Cash flow)이 왜곡되어 ODA의 정확한 흐름을 측정하기가 어려웠으며, 또한 '양허 성의 의미'(concessional in character)를 공여국 또는 수원국 시각에서 각각 달리 해석할 수 있는 점이 존재하여 공여국들 간에도 유상차관의 분담노력이 공정하게 평 
가되지 못했다는 비판적 시각이 존재해왔다. 2000년대 들어 프랑스, 독일 등 일부 공여국들이 대부분의 유상원조 공여국과는 달리 기존 증여율 기준율(cut-off rate) $25 \%$ 를 충족시킬 수 있는 낮은 이자율의 자금을 국제금융시장에서 차입하여 (unsubsidized loans) 개도국에 ODA 차관형태로 재 대출이 가능해지게 되었다.1) 따 라서 그러한 비보조(unsubsidized) 차관도 모두 무상원조와 같이 ODA로 취급되어 유상공여국간 그리고 무유상 공여국간 비용분담에 있어서 형평성의 문제가 제기되어 왔다. 또한 차관 공여국들은 저소득국에 대한 상환리스크 때문에 고소득국 위주의 차관공여로 쏠리는 현상을 보여 왔다. 무유상원조의 적절한 비중을 유지하기 위하여 $\mathrm{DAC}$ 는 $\mathrm{ODA}$ 전체에 대한 증여율 수준을 $86 \%$ 이상을 권고하고 있으나 이를 준수하 지 않은 공여국에 대해서는 실질적인 제재조치는 할 수 없는 상황이다. ${ }^{2)}$ RichardManning 전 DAC의장은 금번 회의 결정에 앞서 비보조 경성차관 제공을 억 제하고 저소득국에 더 많은 원조가 무상과 고양허성차관 형태로 가도록 촉구하면서 그렇지 않을 경우 Post-2015 이후 원조방향이 잘못된 방향으로 갈 것이라고 경고한 바 있다(Manning: 2014).

그간 많은 논의 끝에 공여국간 의견일치를 보인 금번의 양허성 차관의 측정방식의 변경은 정체내지 감소되고 있는 $\mathrm{ODA}$ 에 대한 올바른 방향의 비용분담의 유인 (Incentive)을 제공하려는 시도로 보인다. 금번 회의 결과로 양허성 계산 시 상환액 의 현재가치 산정에 가장 탄력적으로 영향을 미치는 중요 변수인 할인율은 공여국의 차관제공 비용과 개도국에 대한 대출위험을 감안한 할인율을 개도국 소득그룹별 $10 \%$ 이하로 적용하여 축소 조정하게 되었다. 또한 이러한 할인율 적용으로 인한 $\mathrm{ODA}$ 적 용 기준율을 초과하는 증여율만을 차관의 $\mathrm{ODA}$ 로 인정하였고, 전체 $\mathrm{ODA}$ 는 이러한 차관의 증여율과 무상원조를 합한 '증여치(grant equivalent)'를 ODA와 동일한 액수 로 계상토록 하였다. 따라서 무상원조의 비중이 높을수록 그리고 차관의 양허성이 높을수록 더 $\mathrm{ODA}$ 로 산정되게 되었다. 여기서 기존방식으로는 기준율이상의 양허성

1) 예를 들면 약 $2 \%$ 의 이자율을 가진 10 년 만기 채권을 차입하여 $4.75 \%$ 이자율을 가진 거치기간 없는 15년 상환의 차관으로 재대출하면 기존의 증여율 기준을 충족시킬 수 있다. 실제로 2011 및 2012년에 EU, 프랑스, 및 독일은 비보조차관을 양허성 ODA차 관으로 포함하여 보고하였다(Colin: 2014).

2) 차관의 비중이 $50 \%$ 인 경우 $86 \%$ 의 증여율을 충족시키기 위해서는 차관의 증여율이 최 소한 $72 \%$ 가 되어야하는데 2010년 프랑스의 경우 $86 \%$ 를 충족시키지 못했다 (DCD/DAC(2013)2). 
개발차관은 모두 ODA로 인정을 받았으나 새로운 방식으로 산출된 기준율 이하의 금 액은 비 $\mathrm{ODA} \mathrm{TOSD}$ (지속가능한 개발을 위한 총 공적지원)로 기록되며 개발차관 액 수 전부(face value)는 TOSD로 나타나게 된다(OECD/DAC/STAT(2014) 1).

금번 이러한 측정방식의 변경합의를 DAC Solheim 의장은 '커다란 진전이고 이제 모든 사람이 행복하다'라고 표현하고 있는데(Hinchberger: 2014) 기본적으로 보다 객 관적이고 공정하게 공여국들의 비용분담 노력을 반영하려는 시도로 이해된다. 금번 합 의사항이 양허성 산출방법 변경이라는 다소 기술적인 사항을 포함하고 있기는 하나 42 년 만에 $\mathrm{ODA}$ 정의가 수정되는 중요한 역사적인 사건이라고 판단되며 이하에서는 금번 양허성 차관의 증여율 측정방식 변경에 따른 $\mathrm{ODA}$ 변화와 시사점을 살펴보고자 한다.

\section{2. 새 할인율 적용에 따른 증여율의 변화}

기존 유상원조 양허성 측정방식은 공여국의 비용에 비하여 과다하게 계상되어왔다 는 지적을 받아왔다. 특히 $10 \%$ 의 할인율 적용은 공여국의 자본기회비용에 비하여 너 무 높게 책정되어있어서 양허성이 과도하게 높게 산출되어왔다. 양허성 차관 상환액 의 현재가치 산정시 적용되는 할인율은 통상적으로 자본의 기회비용을 의미하며 따 라서 국가별로 차이가 나기 마련이다. 공여국과 수원국의 할인율도 차이가 나는데 공여국의 자본기회 비용이 수원국보다 낮다고 보기 때문에 차관제공이 원조로서의 근거를 지닌다. 원조의 질 측정 시 차관의 양허성이 높을수록 그리고 무상원조의 비 율이 높을수록 원조의 질이 높아지는데3) 같은 액수의 원조를 제공한다 할지라도 ODA차관을 제공하는 국가는 무상원조(증여율 $100 \%$ 를 제공하는 국가보다 원조의 질 이 낮게 평가는 받겠지만 실질적으로 비용부담은 적게 된다.

앞서 언급하였듯이 기존의 양허성 산정은 양허성 기준율 $25 \%$ 이상의 차관액 전부 를 $\mathrm{ODA}$ 로 인정하였고 $10 \%$ 의 할인율 역시 현 국제이자율 수준을 감안시 너무 높게 책정되어 상환액의 현재가치를 너무 낮게 산정함으로써 증여율을 과대하게 높여놓았 다. ${ }^{4)}$ 또한 현행 순지출방식의 ODA 계상방식은 이자상환은 미 고려하고 원금상환만

3) 참고로 타이드(tied)원조는 양허성을 상쇄시켜 원조의 실질가치를 감소시키므로 원조의 질을 저하시킨다. 
net으로 처리하여 이 또한 ODA 수준을 높게 만들었다. 이러한 이자 미상환 처리로 인하여 매년 약 50억불이나 많게 (순)ODA가 계상되었다(Tew: 2013).

이러한 문제점들을 감안하여 기존 유상원조의 양허성 측정방식인 $10 \%$ 의 할인율 및 $25 \%$ 의 ODA 기준율 적용을 변경하여 개도국 소득그룹별로 할인율을 달리 적용하고 그에 따른 $\mathrm{ODA}$ 인정율을 각각 달리하였다. 또 기준율 $(25 \%)$ 이상의 양허성차관액 전 부에 대한 $\mathrm{ODA}$ 인정 계상에서 금번에 별도로 기준율을 넘는 증여율만을 ODA로 인 정하게 되었다. 위험조정증여치(risk adjusted grant equivalent) 방식으로 변경하여 적용되는 할인율을 $\mathrm{IMF}$ 이자율(현 5\%)5)에 국가그룹별로 디폴트 위험6)을 감안한위 험조정율(risk-adjusted discount rate)을 더하는 방식으로 하여 고중소득국(UMIC) $6 \%(+1 \%)$, 저중소득국 $(\mathrm{LMIC}) \quad 7 \%(+2 \%), \quad$ 최빈국 $(\mathrm{LDC})$ 및 기타저소득국(OLIC) $9 \%(+4 \%)$ 의 새 할인율을 적용하게 되었다. 단, $10 \%$ 이하의 할인율 적용으로 증여율 은 상대적으로 낮아지게 되나 ODA로 계상될 수 있는 기준율을 UMIC $10 \%$, LMIC $15 \%, \mathrm{LDC} 45 \%$ 로 새로이 정하였다. 할인율의 축소조정은 공여국간 공감을 얻은 상 태이었으나 할인율 결정수준에 대해서는 의견 일치가 쉽지 않은 부분이었다. OECD 의 공적지원수출금융협약(arrangement on officially supported export credits)하 양허성 수준(concessionality level)을 측정하는데 사용되는 보다 현실적인 차별할인 율(DDRs: Differentiated Discount Rates)7)을 적용하자는 논의도 있었고 (DCD/DAC(2013) 2) 위험조정율 보다는 위험면제율(Risk-free rate)을 적용하자는 주장도 있었다(ONE, 2014). 위험조정율을 적용하면 공여국이 더 많은 ODA로 기록 하기 위하여 채무상환이 어려울 수 있는 즉 위험리스크가 큰 저소득국에 오히려 차 관을 더 제공하려고 하기 때문이고 또 현 $\mathrm{ODA}$ 보고 시스템 하에서는 디폴트 발생 시 채무면제를 ODA로 인정해주고 있어서 이중계상이 될 수 있기 때문이다.

4) 또한 기존의 양허성산출방식에는 차관 상환에 실질적으로 영향을 미치는 물가상승이나 환욜변동을 감안하고 있지 않는 문제점도 있다. 공여국의 인플레이션과 환율하락 발생 시 실질 증여율이 상승하는 효과를 가진다(정우용: 2006 참조).

5) IMF는 $10 \%$ 보다 훨씬 낮은 개별 공여국별 할인율을 적용하여오다가 2013년 저소득국 (LICs)에 대해 $5 \%$ 로 단일화하고 증여율 기준율을 $35 \%$ 로 정하였다.

6) 디폴트 위험 또는 크레딧 위험은 공여국의 금융비용에 추가되는 재원으로 반영된다.

7) DDRs은 평균 상업참고금리(CIRR: Commercial Interest Reference Rate)에 마진을 합 한 것으로 국가별로 매년 다르며 최근 $5 \%$ 이하의 수준을 보이고 있다. 
결국 논의의 결과 $\mathrm{IMF}$ 의 할인율 $(5 \%)$ 에 소득그룹별 위험 프리미엄을 결합하여 새 할인율이 결정되었다. 금번의 새로운 시스템 하에서는 소득이 낮은 국가일수록 높은 할인율이 적용되어 증여율을 높일 수 있고 동일한 차관일지라도 소득이 높은 국가보 다는 낮은 국가에 공여되면 더 많은 $\mathrm{ODA}$ 로 기록될 수 있다. 증여치에 대한 개념은 일찍이 세계은행의 Leipziger(1983)가 주창하였는데 위와 같은 유상원조 측정의 문 제점을 제기하여 양허성 기준율 이상의 증여 율만을 무상원조와 포함하여 ODA로 계 상하자고 주장한 바 있다. 무상비중을 늘리거나 또는 차관의 양허성을 증가함으로써 전체적인 증여율을 개선할 수 있고 따라서 $\mathrm{ODA}$ 자체도 규모가 증대될 수 있다.

이러한 양허성차관의 증여율 측정 방식변경으로 $10 \%$ 이하의 할인율 적용은 단기적 으로는 기존 ODA포함액의 하락이 불가피하나, 소득수준이 낮은 그룹에 대한 지원일 수록 양허성이 증가하여 상대적으로 이러한 나라들에 대한 ODA 제공을 보다 유도하 는 효과를 가진다고 볼 수 있다.

\section{3. 새 증여율과 ODA 변화}

새로운 증여율 산정방법 도입은 외형상 $\mathrm{ODA}$ 규모 변화에도 영향을 미친다. 우선 기존 양허성 산출조건과 비교하여 새 기준율 적용 시 양허성 조건의 개선효과가 발 생된다고 볼 수 있다. 기존 양허성 기준율과 동일한 지원조건일 때 새 증여율이 $\mathrm{UMIC}, \mathrm{LMIC}, \mathrm{LDC}$ 모두 각각의 기준율에 못 미쳐 $\mathrm{ODA}$ 로 인정되지 못하게 되었다. 예컨대 기존 최소한의 증여율 기준율을 상회하는 조건(25.1\%)의 차관(예; $4 \%$ 이자 율, 3 년 거치, 9 년 만기)을 소득그룹별 적용할 때 새로운 할인율 $(6 \%, 7 \%, 9 \%)$ 적용 방식에 따르면 증여율이 UMIC는 9.4\%, LMIC는 $13.7 \%, \mathrm{LDC}$ 는 $21.6 \%$ 에 불과하여 각각 새로운 기준율에 못 미쳐(10\%, $15 \%, 45 \%)$ 모두 ODA로 불인정된다(하단 그래 프 참조). 따라서 새 증여율 산정방식 기준에 따르면 기존의 지원조건보다 더 개선하 여야만 $\mathrm{ODA}$ 로 인정받을 수있게 되었다. 예컨대 이자율을 $1 \%$ 추가로 낮추면 UMIC 와 $\mathrm{LMIC}$ 는 증여율이 각각 $14 \%, 18 \%$ 로 높아져 $\mathrm{ODA}$ 를 충족시키지만 $\mathrm{LDC}$ 는 증여율 이 $26 \%$ 밖에 안 되어 여타 조건(거치 및 만기)을 훨씬 더 개선하여야 한다. $\left.{ }^{8}\right)$

8) 거치 및 만기를 각각 5년 및 25년으로 늘리면 증여율이 기준율을 갓 넘긴 $45.4 \%$ 에 달 하여 ODA조건을 충족시킨다. 


\section{증여율 비교}

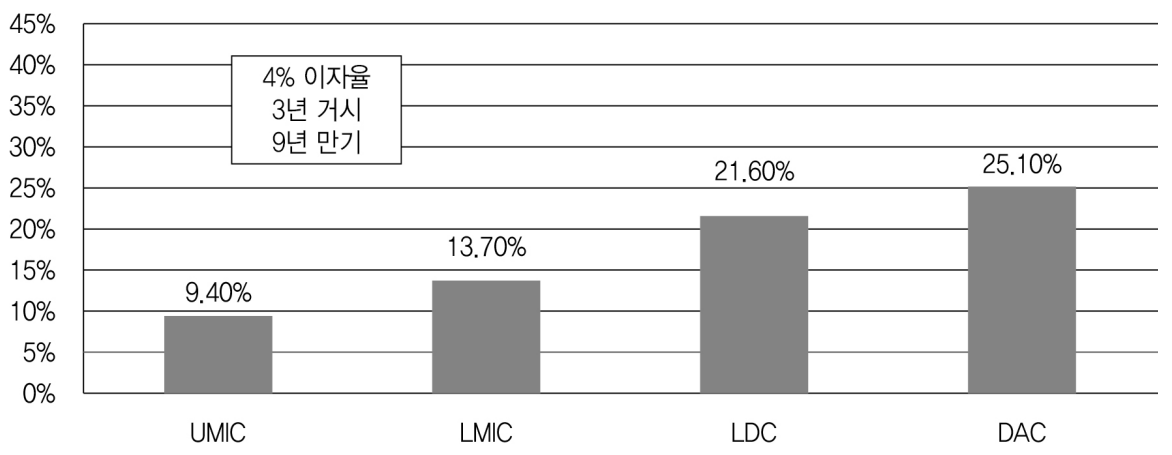

한편, 증여치 개념 도입으로 인한 $\mathrm{ODA}$ 변화를 살펴보면 당해 연도의 약정기준시 의 $\mathrm{ODA}$ 수준과 순지출시 $\mathrm{ODA}$ 수준을 비교하여 $\mathrm{ODA}$ 증감 효과유무를 알아볼 수 있다. 단, 자료제약으로 소득그룹별 할인율을 적용하지 못하고 기존 통계치의 할인율 (10\%)을 사용하였고 약정기준은 약정 시 증여치가 산출되고 통계적으로 보고가 이루 어진다고 보았다. 최근 5 년 간(2008 2012) $\mathrm{DAC}$ 전체의 양자 $\mathrm{ODA}$ (약정기준)는 1,170 억불수준에서 1,050 억불수준으로, 그리고 양자 증여율도 $67 \%$ 수준에서 $64 \%$ 수 준으로 하락하고 있는 추세이며 유상 ODA는 약 200억불 수준에서 다소 늘어나고 있 는 추세이다. $\mathrm{DAC}$ 전체의 양자 $\mathrm{ODA}$ (약정기준)와 순지출 $\mathrm{ODA}$ 규모를 할인율을 $10 \%$ 로 하여 증여치 도입 시의 차이를 살펴보았을 때 아래 그래프에서 보는 바와 같이 $\mathrm{ODA}$ 증여치가 순지출 ODA보다 큰 흐름을 보이고 있다. 새로운 ODA 산출방식에 따 라 증여치는 약정 $\mathrm{ODA}$ 보다 당연히 적은 수준을 보이고 있으나 원금상환을 반영하는 순지출 $\mathrm{ODA}$ 보다는 9\% 27\% 이상 높은 수준을 나타내고 있다. 즉 새로운 증여율 계 산방법 도입으로 적용되는 $\mathrm{ODA}$ 증여치가 할인율 하락으로 인하여 자연히 감소하게 되나 순지출 기준과 비교하면 그래도 높은 수준을 보이는 바, 순지출 ODA의 채무 상환효과를 상회하는 결과로 볼 수 있다. 이러한 ODA의 증대효과는 향후 양허성차 관의 급격한 감소가 발생하지 않는 한 계속될 것으로 예상된다. 


\section{증여치 도입과 양자 ODA변화}

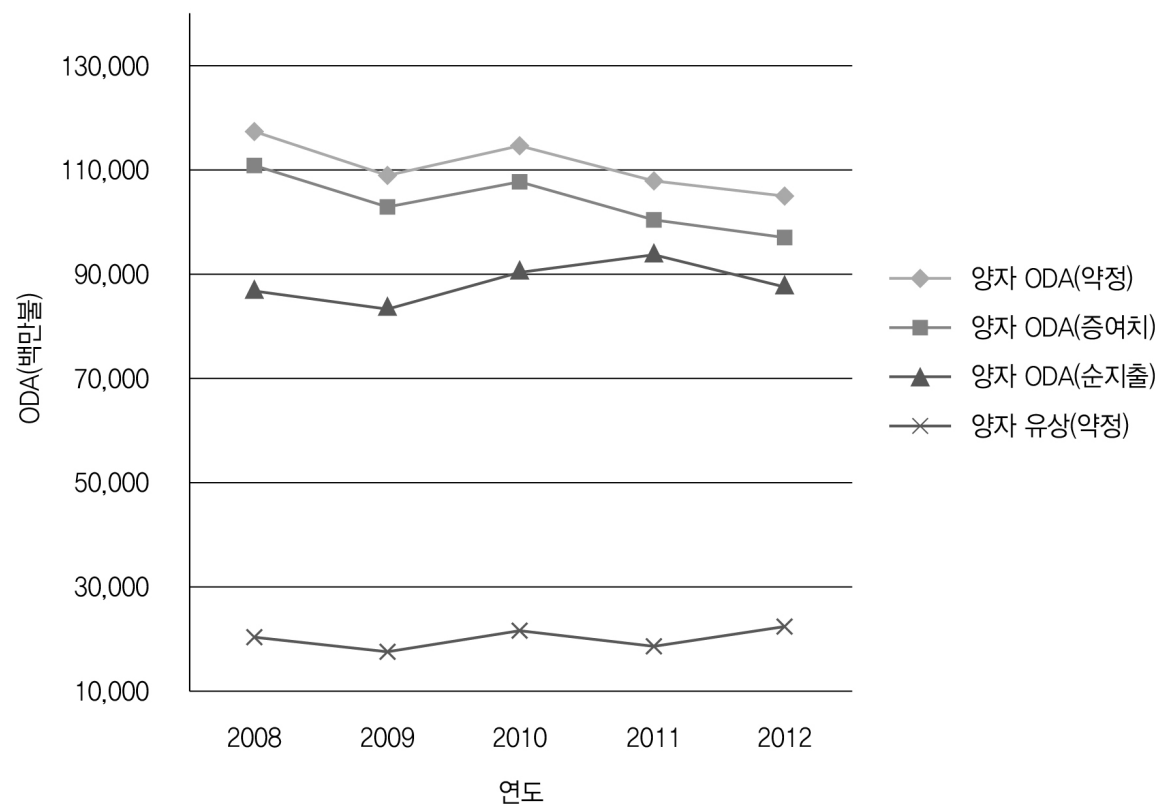

출처: 2014 숫자로 보는 ODA, 한국수출입은행, OECD DAC Table 22.

주요 양자원조 차관공여국에 대한 증여치 도입 전후의 $\mathrm{ODA}$ 규모 변화 정도를 살

펴보면(〈표 1〉 참조)할인율을 $10 \%$ 로 할 때9) 2012년 기준 양자 $\mathrm{ODA}($ 약정)는 $\mathrm{DAC}$ 전 체로는 8,045 백만 불 $(7.7 \%)$ 의 ODA가 감소되나(105,092백만불-97,047백만 불) 현행 ODA 산출방식의 순지출 기준으로는 8,473백만 불(9.6\%)이 더 증가하게 된다(97,047 백만 불-88,574백만 불). 특히 유상원조를 많이 제공하고 증여율이 낮은 프랑스와 독일의 경우 $\mathrm{ODA}$ 증여치가 상대적으로 크게 하락하게 되나(각각 $26.6 \%, 17.2 \%$ ) 현 순지출 기준으로는 오히려 ODA가 각각 $5.5 \%$ (440백만 불), $18.2 \%$ (1,562백만 불)가 증가하는 모습을 보인다. 전술한 바와 같이 증여율이 낮은 프랑스와 독일은 이자율 이 각각 $2.7 \%, 2.2 \%$ 로 $\mathrm{DAC}$ 회원국 중 가장 높고(DAC평균은 $1.5 \%$ ) 비 양허성차관 을 제공하는 $\mathrm{IBRD}$ 의 가장 높은 이자율이 $2.8 \%$ (2011년)인 점과 비교되어 비보조 (unsubsidized)차관 제공국이라는 비판을 받아왔다. 반면, 증여율이 높은 이태리나 한국의 경우 $\mathrm{ODA}$ 증여치가 상대적으로 소폭 하락하여 각각 19 백만불 $(2.2 \%), 134$ 백

9) 마찬가지로 자료 제약으로 양자 ODA증여치 산출에 기존 $10 \%$ 의 할인율을 일괄 적용 하였다. 
만 불(7.6\%) 하락에 그치고 있으나, 순지출 ODA와의 비교 시에는 $\mathrm{ODA}$ 증여치가 각 각 209 백만 불(33.5\%), 436백만 불(36.9\%)의 상승효과를 나타내고 있다. DAC 전체 로는 $\mathrm{ODA}$ 증여치가 8,473 백만 불 $(9.6 \%)$ 의 $\mathrm{ODA}$ 증액 효과를 보이고 있다. 따라서 $\mathrm{ODA}$ 증여치 도입으로 인하여 현행 순지출 기준의 $\mathrm{ODA}$ 실적보다는 외형적으로는 증 액되는 효과가 발생된다고 볼 수 있다.

〈표 1〉 증여치 도입과 주요 차관공여국의 양자 ODA 변화(2012년)

(단위: 백만 불, \%)

\begin{tabular}{c|r|r|r|r|r|r|r}
\hline & $\begin{array}{c}\text { 양자ODA(A) } \\
\text { (약정기준) }\end{array}$ & $\begin{array}{c}\text { 유상ODA } \\
\text { (양자) }\end{array}$ & $\begin{array}{r}\text { 양지증여율 } \\
\text { (10\%할인율) }\end{array}$ & $\begin{array}{c}\text { 양자ODA(B) } \\
\text { (증여치) }\end{array}$ & 증감(A-B) & $\begin{array}{r}\text { 양자ODA(C) } \\
\text { (순지출기준) }\end{array}$ & 증감(B-C) \\
\hline 호주 & 4,662 & 43 & 80.6 & 4,654 & -8 & 4,550 & 104 \\
\hline 벨기에 & 1,343 & 38 & 83.3 & 1,337 & -6 & 1,433 & -96 \\
\hline 프랑스 & 11,399 & 5,784 & 47.6 & 8,368 & $-3,031$ & 7,928 & 440 \\
\hline 독일 & 12,253 & 3,873 & 45.6 & 10,146 & $-2,107$ & 8,584 & 1,562 \\
\hline 이태리 & 852 & 224 & 91.6 & 833 & -19 & 624 & 209 \\
\hline 일본 & 17,270 & 10,304 & 75.9 & 14,787 & $-2,483$ & 6,402 & 8,385 \\
\hline 한국 & 1,753 & 1,111 & 87.9 & 1,619 & -134 & 1,183 & 436 \\
\hline 포르투갈 & 402 & 281 & 65.1 & 304 & -98 & 397 & -93 \\
\hline DAC & 105,092 & 22,472 & 64.2 & 97,047 & $-8,045$ & 88,574 & 8,473 \\
\hline
\end{tabular}

출처: 2014 숫자로 보는 ODA, 한국수출입은행, OECD DAC Table 22.

우리나라의 $\mathrm{EDCF}$ 차관의 경우 변경된 증여율 산정방식을 적용하여 소득 국가군에 따라 할인율을 달리 적용하여 조정된 증여율과 이에 따른 차관 조정액을 산출하여 보았다(〈표 2〉 참조). 2013년 승인된 베트남 등 중저소득국 7국 13개 사업과 르완다 등 최빈국 6 국 8 개 사업 총 21 개 사업에 대한 차관액은 모두 기존보다 낮은 할인율 적용으로 자연히 조정 차관액보다 적게 된다. 당초 차관액보다 221 억 불 $(1,200$ 백만 불-979백만 불)이 감소(18.4\%)하게 된다. 그러나 21 개 사업 모두의 조정 증여율이 각각의 기준율보다 높아 $\mathrm{ODA}$ 로 다 인정이 된다. 따라서 단기적으로 동일한 $\mathrm{ODA}$ 수 준을 유지하려면 무상으로 부족분을 보충하여야 한다. 또한 그룹별로 볼 때 LMIC보 다 $\mathrm{LDC}$ 에 더 높은 증여율이 적용됨에 따라 조정 차관액이 $\mathrm{LMIC}$ 는 $23.7 \%$ (161백만 
불) 감소하고 $\mathrm{LDC}$ 는 $11.4 \%$ (59백만 불)감소하는데 그치고 있으므로 조정 차관액의 감소폭을 축소하기 위해서는 소득수준이 높은 국가군보다는 저소득국가에 더 지원을 할 필요가 있다.

〈표 2〉 EDCF 증여율 변화(2013년 승인기준)

(단위: 백만 불, \%)

\begin{tabular}{|c|c|c|c|c|c|}
\hline $\begin{array}{c}\text { 국가 } \\
\text { (그룹) * }\end{array}$ & 사업명 & 차관액 & 증여율 & $\begin{array}{c}\text { 조정 } \\
\text { 증여율** }\end{array}$ & $\begin{array}{l}\text { 조정 } \\
\text { 차관액 }\end{array}$ \\
\hline $\begin{array}{l}\text { 르완다 } \\
\text { (LDC) }\end{array}$ & 르완다 국립대학교 건립사업 & 51.25 & 91.00 & 88.55 & 45.38 \\
\hline \multirow{2}{*}{$\begin{array}{l}\text { 모잠비크 } \\
\text { (LDC) }\end{array}$} & 마푸토 위생매립장 건립사업 & 48.62 & 91.00 & 88.55 & 43.05 \\
\hline & 남풀라-나메틸 도로 건설사업 & 75.44 & 91.00 & 88.55 & 66.80 \\
\hline \multirow{2}{*}{$\begin{array}{l}\text { 미얀마 } \\
\text { (LDC) }\end{array}$} & $\begin{array}{l}\text { 500kV Taungoo-Kamanat } \\
\text { 송전망 구축사업 }\end{array}$ & 100.00 & 91.00 & 88.55 & 88.55 \\
\hline & IT 인프라네트워크 구축사업 & 55.87 & 91.00 & 88.55 & 49.47 \\
\hline \multirow{5}{*}{$\begin{array}{l}\text { 베트남 } \\
\text { (LMIC) }\end{array}$} & 기후변화대응 프로그램(2차) & 20.00 & 74.67 & 61.57 & 12.31 \\
\hline & $\begin{array}{l}\text { 국립이비인후과병원 } \\
\text { 의료기자재 공급사업 }\end{array}$ & 19.00 & 84.34 & 73.73 & 14.01 \\
\hline & 하노이약학대학 건립사업 & 45.00 & 86.69 & 76.99 & 34.65 \\
\hline & 티엔탄 상수도사업(2차)(보충) & 15.00 & 86.69 & 76.99 & 11.55 \\
\hline & 베트남 흥하교량 건설사업 & 117.00 & 86.69 & 76.99 & 90.08 \\
\hline \multirow{2}{*}{$\begin{array}{l}\text { 스리랑카 } \\
\text { (LMIC) }\end{array}$} & 데두루 오야 상수도 사업 & 58.16 & 86.24 & 76.43 & 44.45 \\
\hline & 루완웰라 상수도 사업 & 20.53 & 86.24 & 76.43 & 15.69 \\
\hline $\begin{array}{l}\text { 에티오피아 } \\
\quad \text { (LDC) }\end{array}$ & $\begin{array}{l}\text { 모조-하와사 고속도로 } \\
\text { 건설사업 - Phase 1(Lot 2) } \\
\text { 메키-주웨이 구간 }\end{array}$ & 100.00 & 91.00 & 88.55 & 88.55 \\
\hline $\begin{array}{l}\text { 온두라스 } \\
\text { (LMIC) }\end{array}$ & 농촌 태양광 전력화사업 & 44.75 & 87.59 & 78.13 & 34.96 \\
\hline $\begin{array}{c}\text { 우즈베키스탄 } \\
\text { (LMIC) }\end{array}$ & 국립아동병원 건립사업 & 102.85 & 87.50 & 76.99 & 79.18 \\
\hline \multirow{2}{*}{$\begin{array}{l}\text { 인도네시아 } \\
\text { (LMIC) }\end{array}$} & 바탐 하수처리시설 구축사업 & 50.00 & 86.35 & 76.43 & 38.22 \\
\hline & 경찰청 고속순시선 공급사업 & 35.00 & 86.28 & 76.43 & 26.75 \\
\hline
\end{tabular}




\begin{tabular}{|c|c|c|c|c|c|}
\hline $\begin{array}{c}\text { 국가 } \\
\text { (그룹) * }\end{array}$ & 사업명 & 차관액 & 증여율 & $\begin{array}{c}\text { 조정 } \\
\text { 증여율** }\end{array}$ & $\begin{array}{c}\text { 조정 } \\
\text { 차관액 }\end{array}$ \\
\hline $\begin{array}{l}\text { 잠비아 } \\
(\mathrm{LDC})\end{array}$ & $\begin{array}{l}\text { 공공안전정보화 시스템 } \\
\text { 구축사업 }\end{array}$ & 41.53 & 91.00 & 88.55 & 36.77 \\
\hline $\begin{array}{l}\text { 카메룬 } \\
\text { (LMIC) }\end{array}$ & 가루아 종합병원 건립사업 & 57.46 & 86.69 & 76.99 & 44.24 \\
\hline $\begin{array}{l}\text { 캄보디아 } \\
\text { (LDC) }\end{array}$ & 다운트리댐 개발사업 & 46.70 & 91.01 & 88.55 & 41.35 \\
\hline $\begin{array}{l}\text { 필리핀 } \\
\text { (LMIC) }\end{array}$ & $\begin{array}{l}\text { 팜팡가 지역 통합재난위험감축 } \\
\text { 및 기후변화적응 }\end{array}$ & 96.05 & 86.24 & 76.43 & 73.41 \\
\hline 소계 & 21건 & $1,200.21$ & & & 979.44 \\
\hline
\end{tabular}

* 소득별 그룹구분은 2014,2015,2016년 기준(DAC List of ODA Recipients).

** 연 2회(6개월) 원금균등상환기준으로 산출.

출처: 수출입은행 대외경제협력기금 업무통계자료 http://www.edcfkorea.go.kr/edcf/info/statis/ report.jsp.

\section{4. 결론 및 시사점}

원조차관의 양허성 측정과 적용에 대한 문제점이 $\mathrm{DAC}$ 공여국간 오랫동안 제기되 어오다가 최근 $\mathrm{DAC}$ 고위급회의에서 새로운 양허성 산출방법과 $\mathrm{ODA}$ 정의가 변경토 록 합의되었다. 기본적으로 금번의 양허성 측정방식의 변경의 목적은 $\mathrm{ODA}$ 계상에 있어 유상보다는 무상의 비중을 더 크게 하고, ODA에 더 계상될 수 있는 높은 양허 성차관 제공을 유인하도록 하고, 그리고 고소득국보다는 가능한 저소득국에 대한 높 은 양허성을 제공토록 하려는 것이라고 볼 수 있다. 그럼으로써 DAC의 무상원조국 들과 비교하여 유상원조국들의 원조분담을 공정하게 측정하고 반영할 수 있을 것으 로 보인다.

금번 새로이 개정된 증여율 산정방식으로 특히 낮아진 할인율의 적용으로 자연히 대상 ODA보다는 ODA 증여치(grant equivalent)가 축소되는 모습을 보인다. 따라서 공여국의 유상원조가 증가할 경우 단기적으로는 $\mathrm{ODA}$ 는 감소되고, 정체 내지 감소할 경우 $\mathrm{ODA}$ 는 증가하는 모습을 보일 것이다. 그러나 중장기적으로는 순지출시 차관의 원리금을 차감할 필요가 없기 때문에 약정시의 $\mathrm{ODA}$ 수준은 증액되는 모습을 보일 것이다. 이는 $\mathrm{ODA}$ 증여치의 수준이 할인율 하락으로 인한 증여율 감소에도 불구하 
고 순지출 기준시의 상환효과로 인한 수준보다 크기 때문이라고 볼 수 있다. Post-2015이후 ODA 0.7\% 양적달성 목표와 관련하여 금번의 ODA 증여치 개념의 도입은 별도의 추가적인 재원 투입 없이 $\mathrm{ODA}$ 증대효과를 가져다줄 것으로 보인다. 이러한 $\mathrm{ODA}$ 의 증대효과는 향후 양허성차관의 급격한 감소가 발생하지 않는 한 계속 될 것으로 예상된다.

한편, 각 소득그룹별 적용 할인율이 하락되어 동일한 증여율을 유지하기 위해서는 기존방식의 지원조건보다는 보다 더 양허성이 증가되는 지원조건이 필요하고 따라서 양허성은 전보다 더 개선되는 효과를 나타낼 것으로 보인다. 특히 고소득국에 대한 적용 할인율이 상대적으로 작으므로 차관 공여국들은 저소득국 등에의 차관을 더 증 가하여 $\mathrm{ODA}$ 규모를 증대시키려할 것이다.

우리나라의 양허성차관인 $\mathrm{EDCF}$ 의 경우 높은 양허성을 보이지만 새로 개정된 증여 율 기준율 적용으로 인하여 단기적으로는 $\mathrm{ODA}$ 가 하락하는 효과를 가지게 된다. 따 라서 동일수준이상의 $\mathrm{ODA}$ 유지를 위해서는 무상으로 보충을 하여야 하며 상대적으 로 소득수준이 높은 그룹보다는 $\mathrm{LDC}$ 등 하위소득그룹에 대한 지원강화가 양허성을 증가시켜 $\mathrm{ODA}$ 수준을 덜 하락시키게 된다.

금번에 원칙적으로 합의된 양허성 차관의 새로운 측정방법과 적용, 그리고 ODA 통계 보고 등은 2015년 말까지 그 구체적 방안이 마련될 것으로 보인다. 특히 양허 성 원조의 양적 질적 수준을 저하시키지 않으면서 공여국간 공평한 비용분담을 유인 하는(incentives) 합리적인 보고체계가 도입되리라고 본다. Post-2015이후 개발재원 확충 방안과 관련하여 지속가능한 ODA 지원을 통한 국제사회에의 우리의 기여가 $\mathrm{DAC}$ 의 금번 개혁방안을 통해 지속적으로 향상될 수 있도록 하는 전략마련이 필요할 것으로 본다. 


\section{참고문헌}

정우용(2006), 양허성 원조차관(aid loans) 제공의 실질비용과 제약요인, 국제 개발협력. 2006년 제2호(2006. 7) pp.35-46

한국수출입은행(2014), 2014 숫자로 보는 ODA

한국수출입은행(2014), 대외경제협력기금 업무통계자료,

http://www. edcfkorea.go.kr/edcf/info/statis/report.jsp

Colin, S.(2014), A Matter of High Interest, EURODAD,

http://www. eurodad.org/files/pdf/52dfd0d16a841. pdf

DCD/DAC(2013)2, Loan Concessionality in DAC Statistics,

http://www. oecd.org/officialdocuments/publicdisplaydocum entpdf $/$ ? cote $=$ DCD/DAC(2013) $2 \&$ docLanguage $=$ En

DCD/DAC/STAT(2014) 1, Modernising the Reporting on ODA Loans

-Risk-Adjusted Grant Equivalents and Other Approches, http://www. oecd.org/dac/externalfinancingfordevelopment/ documentupload/DCD_DAC_STAT_2014_1_ENG.pdf

Hinchberger, B(2014), OECD-DAC reaches compromise on concessional loans, .

Leipziger, D(1983), Lending Versus Giving: The Economics of Foreign

Assistance, WorldDevelopment,Vol.11,No.4.pp.329-335

Manning, R(2014), Helping the Poor or Cooking the Books: How

Concessional is Concessional aid?,

$\operatorname{OECD(2014)}$ Development Cooperation Report

ONE(2014), The 2014 Data Report: Fighting Poverty and Financing Africa's Future,

http://one_org_international.s3.amazonaws.com/international/media/inter national/2014/10/One_DATA_Report-2014-9-19-14-RGB.pdf

Tew, R(2013), ODA Loans: Investments to End Poverty discussion paper, Development Initiatives, http://devinit.org/wp-content/uploads/2013/09/ODA_loans _discussion_ paper3.pdf 